\title{
STUDY OF PROTEASE ACTIVITY OF BACTERIA ISOLATED FROM SOLID WASTE
}

\author{
Smriti Mainali*, Nanu Maiya Khadka*, Bijaya Laxmi Maharjan** and Binod Lekhak* \\ *Central Department of Microbiology, TU, Kathmandu, Nepal. \\ ** Nepal Academy of Science and Technology, Khumaltar, Lalitpur, Nepal.
}

\begin{abstract}
Solid waste is one of the most visible environmental nuisances and major causes of pollution in the urban areas. But a considerable proportion of this waste is decomposable organic matter. The study was designed to study the activity of protease enzyme produced by proteolytic bacteria isolated from solid waste. Solid waste samples were collected from 20 different sites of Kathmandu valley and proteolytic bacteria were isolated by serial dilution and spread plate technique using gelatin incorporated agar media. Among 113 isolates 22 (3 being potent ones) were found to be proteolytic bacteria. Protease enzyme was extracted from the most potent ones by fermentation technology and purified by acetone precipitation method and ammonium sulphate fractionation. The enzyme from Micrococcus spp. was optimally active at $4^{0} \mathrm{C}$ and $\mathrm{pH} 8 \mathrm{while}$ that from another isolate, which remained unidentified, was optimally active at $37^{\circ} \mathrm{C}$ and $\mathrm{pH} 9$. The activity of $60 \%$ salt fraction of the enzymes from both the isolates was maximum. This indicates the possibility of implementation of these enzymes for the management of solid waste by decomposing the proteinous components of the waste.
\end{abstract}

Key words: Solid waste; Enzyme activity; Proteolytic bacteria.

\section{INTRODUCTION}

Rapid and haphazard urbanization has led to increasing volumes of waste being generated in the urban area of Nepal. Various studies carried out since 1976 indicate that around two-thirds of the municipal solid waste generated in Kathmandu Metropolitan City is organic; this has remained relatively unchanged over the years (ICIMOD, 2007; Udas, 2004; IUCN, 1992). Of the rest inorganic components, majority can be recycled and reused with a little amount requiring land-filling (MOPE, 2001). Therefore, the increasing volume of waste being generated would not be a problem if waste was viewed as a resource and managed properly. Majority of the organic fraction of the waste constitutes of starch, lipid, protein, cellulose, hemicellulose and lignin. Almost all of these components can be degraded via specific enzymes. Protein degradation initiates and continues in the presence of proteases. Various proteolytic microorganisms are capable of producing the enzyme protease. This study was carried out to isolate the bacteria exhibiting higher degree of proteolytic activity from solid waste. The research project aims to explore useful microbial flora and their implications in solid waste management through protein degradation.

\section{MATERIALS AND METHODS}

The study was carried out at Research Laboratory of Central
Department of Microbiology, Tribhuvan University, Kirtipur. The waste samples (3 from each site) were collected from 20 different sampling sites of Kathmandu Valley by random sampling method. The sampling was carried out in widemouthed sterilized glass bottle with the help of sterile forceps. Temperature of the waste was measured at the site using thermometer while $\mathrm{pH}$ was measured after transporting the samples to the laboratory using $\mathrm{pH}$ meter. The degradable fraction of the waste was segregated. The gelatin degrading bacteria were screened by dilution technique and spread plate method on mineral base agar amended with $1 \%$ gelatin following incubation at $30^{\circ} \mathrm{C}$ for $24 \mathrm{~h}$. The proteolytic bacteria were detected by observing the zone of hydrolysis after flooding the incubated plate with freshly prepared mercuric chloride. The isolates exhibiting higher degree of activity were selected and subjected to the production of enzyme by fermentation at $30^{\circ} \mathrm{C}$ and $150 \mathrm{rpm}$. The enzyme was extracted by centrifugation at $10000 \mathrm{rpm}$ for 10 minutes at $4^{\circ} \mathrm{C}$ and partially purified by acetone precipitation method (Khatiwada, 2004). The enzyme was assayed by radial agar well diffusion method in nutrient agar supplemented with $1 \%$ gelatin (Dingle et al, 1953).

The enzymes revealing higher degree of activity were fractionated with ammonium sulphate crystals to different saturation. The effect of different incubation temperature (4, $15,26,37,45,60,70$ and $\left.80^{\circ} \mathrm{C}\right)$ and $\mathrm{pH}(4,5,6,7,8$ and 9$)$ of

Author for Correspondence: Mainali S, Central Department of Microbiology, TU, Kathmandu, Nepal. Email: nairanjana1@gmail.com. 


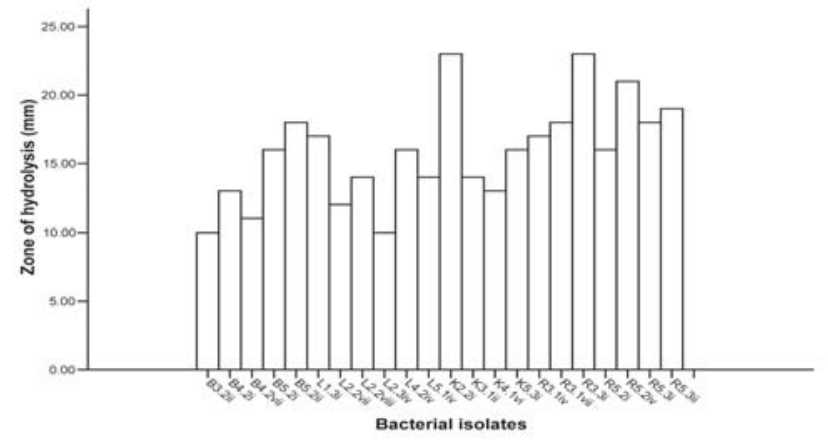

Fig 1: Primary screening of the isolates for extracellular protease on $1 \%$ gelatin agar

Table 1: Secondary screening

\begin{tabular}{|c|c|c|}
\hline S.N & Enzymes from the isolate & Zone of hydrolysis $(\mathbf{m m})$ \\
\hline 1 & $\mathrm{~K} 2.2 \mathrm{i}$ & 16 \\
\hline 2 & $\mathrm{R} 3.3 \mathrm{i}$ & 17 \\
\hline 3 & $\mathrm{R} 5.2 \mathrm{iv}$ & 13 \\
\hline
\end{tabular}

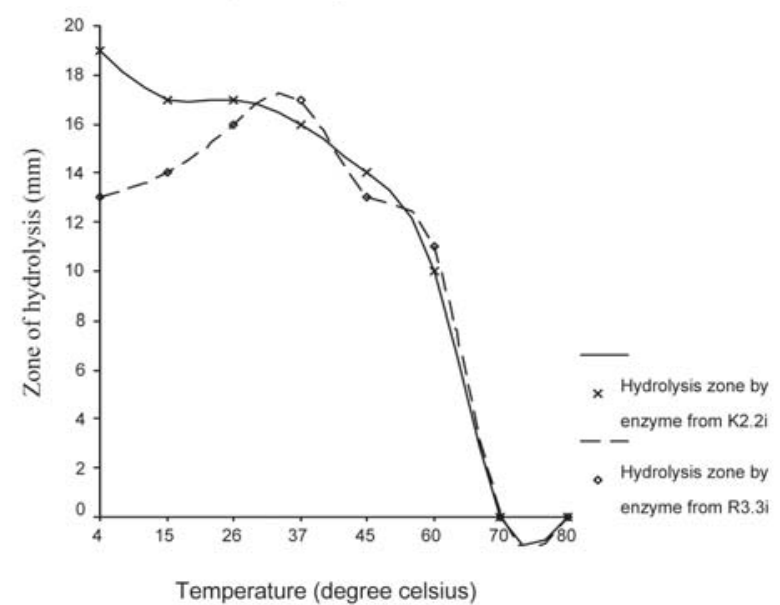

Fig 2: Effect of temperature on the activity of partially purified enzyme

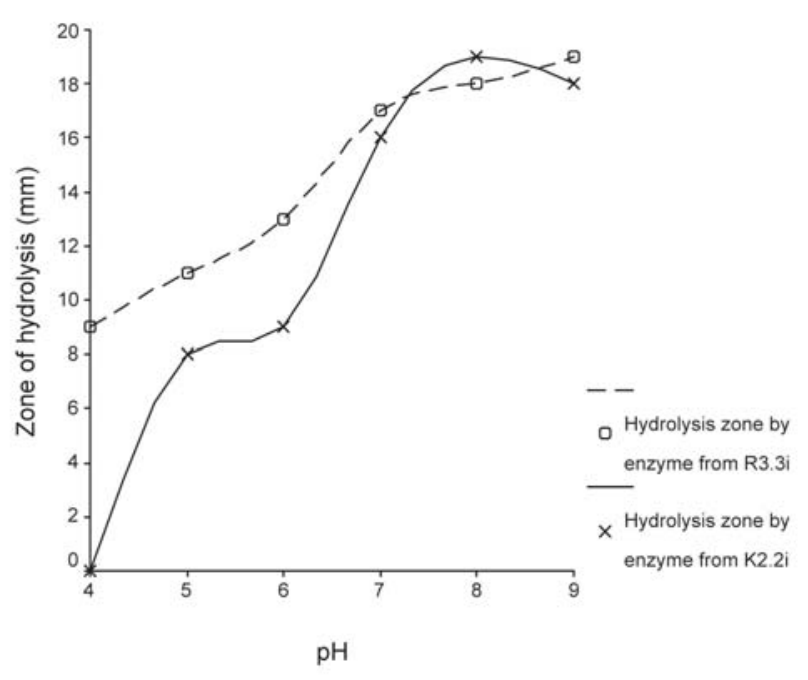

Fig 3: Effect of $\mathrm{pH}$ on the activity of partially purified enzyme

medium on the activity of acetone purified and salt fractionated enzymes were compared. The data obtained were analyzed for ANOVA and paired samples $\mathrm{t}$ - test using statistical software (SPSS version 11.5).

\section{RESULT}

A total of 113 isolates were obtained from all the samples, of which 22 exhibited gelatinase activity (fig. 1). Of these 22 gelatin degrading bacteria, 3 potent producers (Laboratory code: K2.2i, R3.3i and R5.2iv) of gelatinase were selected. Two isolates K2.2i and R5.2iv were identified as Micrococcus spp. while the isolate R3.3i remained unidentified. The crude enzymes from isolates K2.2i and R3.3i revealed similar zone of hydrolysis; however, R5.2iv showed comparatively smaller zone (table 1).

The enzyme from the isolate K2.2i was optimally active at

Table 2: Effect of temperature on the activity of salt fractionated enzyme

\begin{tabular}{|c|c|c|c|c|c|c|}
\hline \multirow{2}{*}{ S.N } & \multirow{2}{*}{ Temperature $\left({ }^{\mathbf{0}} \mathbf{C}\right)$} & \multicolumn{3}{|c|}{ Zone of hydrolysis by enzyme from R3.3i } & \multicolumn{3}{|c|}{ Zone of hydrolysis by enzyme from K2.2i } \\
\cline { 3 - 7 } & & $\mathbf{3 0} \%$ fraction & $\mathbf{6 0 \%}$ fraction & $\mathbf{3 0} \%$ fraction & $\mathbf{6 0} \%$ fraction & $\mathbf{9 0} \%$ fraction \\
\hline 1 & 4 & 15 & 16 & 20 & 22 & 17 \\
\hline 2 & 15 & 16 & 18 & 20 & 22 & 16 \\
\hline 3 & 26 & 19 & 22 & 18 & 20 & 14 \\
\hline 4 & 37 & 20 & 23 & 18 & 18 & 12 \\
\hline 5 & 45 & 18 & 20 & 10 & 10 & 11 \\
\hline 6 & 60 & 14 & 16 & 0 & 0 & 8 \\
\hline 7 & 70 & 0 & 0 & 0 & 0 & 0 \\
\hline 8 & 80 & 0 & 0 & & & 0 \\
\hline
\end{tabular}

Table 3: Effect of pH on the activity of salt fractionated enzyme

\begin{tabular}{|c|c|c|c|c|c|c|}
\hline \multirow{2}{*}{ S.N } & \multirow{2}{*}{$\mathbf{p H}$} & \multicolumn{2}{|c|}{ Zone of hydrolysis by enzyme from R3.3i } & \multicolumn{3}{c|}{ Zone of hydrolysis by enzyme from K2.2i } \\
\cline { 3 - 7 } & & $\mathbf{3 0} \%$ fraction & $\mathbf{6 0 \%}$ fraction & $\mathbf{3 0} \%$ fraction & $\mathbf{6 0} \%$ fraction & $\mathbf{9 0} \%$ fraction \\
\hline 1 & 4 & 0 & 11 & 0 & 8 & 0 \\
\hline 2 & 5 & 0 & 12 & 11 & 12 & 0 \\
\hline 3 & 6 & 13 & 15 & 17 & 20 & 8 \\
\hline 4 & 7 & 19 & 21 & 21 & 22 & 12 \\
\hline 5 & 8 & 21 & 23 & 19 & 20 & 17 \\
\hline 6 & 9 & 21 & 24 & \multicolumn{5}{c|}{} \\
\hline
\end{tabular}


cold temperatures while that from the isolate R3.3i at mesophilic temperature (fig. 2). The enzymes from both the strains were more active in the alkalophilic range of $\mathrm{pH}$ (fig. 3). The activity of the $60 \%$ fractionated enzyme was highest in both the cases (table 2 and table 3 ).

\section{DISCUSSION AND CONCLUSION}

The total amount of waste is still small compared to other countries but still poor government response and weakness of institutions at the local level have resulted in the improper management of the waste. This has ultimately resulted environmental pollution, public health hazards and adverse effects on urban economy that depends heavily on tourism (MOPE, 2001). Regarding the impacts of unmanaged solid waste, this problem is to be addressed seriously. The best approach for improving the environmental performance of solid waste management systems, while keeping them economically affordable and socially acceptable, is via Integrated Solid Waste Management. When integrated together, composting, biogasification and material recycling can provide cost effective ways to manage municipal solid waste (Goen, 1998).

This work has been done to explore highly efficient proteolytic indigenous bacteria for the degradation of protein portion of the waste. The temperature of most of the waste piles was ranging from $18^{\circ} \mathrm{C}$ to mesophilic range (around $35^{\circ} \mathrm{C}$ ) and $\mathrm{pH}$ of almost all the samples was around neutral (6.9 to 7.1). Kendall et al (2005) revealed increasing temperature (1$15^{\circ} \mathrm{C}$ ) for newly placed wastes whereas steady elevated temperature $\left(50-60^{\circ} \mathrm{C}\right)$ was observed in older wastes.

A total of 113 isolates were obtained from these samples, of which only 3 isolates (K2.2i, R5.2iv and R3.3i) were found to be potent producer of proteolytic enzyme. These three bacteria were identified. All the isolates were non - capsulated and non - sporulating gram positive cocci. The isolate K2.2i was oxidative; non - motile; mannose, sorbitol, sucrose and arabinose positive; indole negative and hydrolyzing tween 60. Similarly, the isolate R5.2iv was oxidative; non - motile; sucrose and arabinose positive; indole negative and hydrolyzing tween 60 . Thus the isolates K2.2i and R5.2iv were found to be Micrococcus spp. while the isolate R3.3i was found to be fermentative; producing water soluble red pigment; highly motile; mannose, mannitol, sorbitol, sucrose and raffinose positive; indole negative and hydrolyzing tween 60 potentially. The isolate R3.3i remained unidentified on the basis of the tests performed.

These three bacteria were cultivated in fermentation broth for the production of proteolytic enzyme. The crude enzyme was assayed for further screening. Of these 3 bacteria, the enzymes from two strains, K2.2i and R3.3i produced zone of hydrolysis greater than $15 \mathrm{~mm}$ in diameter and were selected for purification and characterization (according to Fujiwara and Yamamoto, 1987 and Elfadaly et al., 1993). There was no standard protease producing bacteria available and the comparison was made among the screened bacteria themselves. The enzymes were partially purified by acetone precipitation method and then by ammonium sulphate fractionation. The enzymes from both the isolates $\mathrm{K} 2.2 \mathrm{i}$ and R3.3i were active from $4^{\circ} \mathrm{C}$ to $60^{\circ} \mathrm{C}$ while no activity was seen at $70^{\circ} \mathrm{C}$ and above. The enzyme from isolate $\mathrm{K} 2.2 \mathrm{i}$ exhibited high activity at psychrophilic range of temperature while that from isolate R3.3i revealed high activity at mesophilic range of temperature with optimum temperature around $37^{\circ} \mathrm{C}$.

The enzyme from isolate $\mathrm{K} 2.2 \mathrm{i}$ was found to be active from $\mathrm{pH} 5$ to $\mathrm{pH} 9$ while that from $\mathrm{R} 3.3 \mathrm{i}$ was active from $\mathrm{pH} 4$ to $\mathrm{pH}$ 9. Protease from the isolate K2.2i displayed maximum activity at $\mathrm{pH}$ 8. Since the effect of $\mathrm{pH}$ above 9 was not studied, it could not be concluded that whether the optimal $\mathrm{pH}$ for maximum activity of the enzyme from strain R3.3i was 9 or not. Whatever may be the optimum $\mathrm{pH}$ for these enzymes, both were found to be effectively active at alkalophilic $\mathrm{pH}$.

The enzymes from both the bacteria were found to be active at a wide range of temperature and $\mathrm{pH}$. This predicts various important applications of these enzymes. The one this work is concerned is on their application in solid waste management. Both of these enzymes were active and working effectively in the temperature range of environment as well as up to $60^{\circ} \mathrm{C}$. Similarly these enzymes were working at a wide range of $\mathrm{pH}$; from acidic to alkaline range. Because of these characteristics of these enzymes, their use in the management of piled up solid waste via protein degradation could be attempted.

Furthermore, both the enzymes were fractionated with ammonium sulphate crystals to prepare $30 \%, 60 \%$ and $90 \%$ fractions. All the three fractions of both the enzymes were assayed at $37^{\circ} \mathrm{C}$ and $\mathrm{pH} 7$. The $60 \%$ fractions of both the enzymes displayed maximum activity. The activity of these fractions of the enzymes was also studied under different temperatures and different $\mathrm{pH}$. All the fractions of enzyme from isolate $\mathrm{K} 2.2 \mathrm{i}$ and $30 \%$ and $60 \%$ fractions of enzyme from isolate R3.3i were found to be active from $4^{\circ} \mathrm{C}$ to $60^{\circ} \mathrm{C}$. The activity of $60 \%$ fraction of both the enzymes under different temperatures and $\mathrm{pH}$ was found significantly high $(\mathrm{P}<0.05)$ than the activity of respective enzymes purified partially by acetone precipitation.

From the study of the temperature and $\mathrm{pH}$ condition of the piled up solid waste and the activity profile of the obtained enzymes, it can be concluded that both of these enzymes are suitable for their application in solid waste management, although many important aspects like the effect of various inhibitors possibly present in the solid waste, the effect of enormous amount of substrate present in the waste and the effect of various by - products produced during the decomposition of these wastes were not studied in this present work. The enzymes from isolate K2.2i can be applied in the management of solid waste in the cold regions or in the cold seasons whereas that from isolate R3.3i can be applied during warm weathers of mesophilic range of temperature; both under alkaline condition. 


\section{ACKNOWLEDGEMENT}

The authors would like to thank Head of the Department of Microbiology for providing laboratory facilities, Mr. Dev Raj Joshi for his suggestions and all the teaching and nonteaching staffs of the Department for their kind co-operation during the whole work.

\section{REFERENCES}

Chandran, S., Alagarsamy, S. and Pandey, A. 2006. Proteases In Enzyme Technology (Eds Pandey, A., Webb, C., Soccol, C.R. and Larroche, C.); Illustrated reprint; Springer Science + Business Media, Inc; New York. Pp. 319-322.

Dingle J., Reed W.W., Solomona G.L. 1953. The enzymic degradation of pectin and other polysaccharides II - Application of the Cup plate Assay to the estimation of enzymes; Journal of Food Science and Agriculture. Pp. 149-50.

Elfadely, H., Sevella, B. and Nyeste, L. 1993. Fermentation and properties of thermostable proteinase. Acta Alimentaria 22(2): 97-106.

Fujiwara, N. and Yamamoto, K. 1987. Production of an alkaline protease in a low cost medium by alkalophilic Bacillus sp. and properties of the enzyme. Journal of fermentation technology. 65(3): 345-348.
Goen H.O. 1998. Solid Waste Management - Technology Options In: Workbook for training in adopting, applying and operating environmentally sound technologies (Ed: J. Whitelaw); UNEP; Perth. pp. 165-7.

ICIMOD 2007. Waste Management. Kathmandu Valley Environment Outlook. ICIMOD. pp: 73-87.

IUCN. 1992. "Solid waste management in urban Nepal”; NPC/IUCN NCS Implementation Project.

Kendall, L.A., Hanson, J.L. and Yesiller, N. 2005. Integrated temperature and gas analysis at a municipal solidwaste landfill.

http://works.bepress.com/johanson/8

Khatiwada, B. 2004. Characterization of proteases from Bacillus species producing antimicrobial substances. M.Sc. Dissertation. Central Department of Microbiology, Tribhuvan University, Kathmandu, Nepal.

MOPE (Ministry of Population and Environment). 2001. Nepal: State of the Environment, 2001; Kathmandu; MOPE/UNEP/ ICIMOD/NORAD/SACEP.

Udas, R. 2004. Composting as an option in the Municipal Solid Waste Management of Kathmandu Metropolitan City. M.Sc. Dissertation. School of Environmental Science and Management, Pokhara University, Pokhara, Nepal. 